TEME, г. XLIV, бр. 1, јануар - март 2020, стр. 159-171

\begin{tabular}{lr}
\hline \hline Претходно саопштење & https://doi.org/10.22190/TEME180519014F \\
Примљено: 19.5 .2018 & UDK 343.7(497.11 Leskovac)"1782"
\end{tabular}

Ревидирана верзија: 28. 1. 2020.

Одобрено за штампу: 20. 2. 2020.

\title{
РАЗБОЈНИШТВО У ЈАШУЊСКОМ МАНАСТИРУ 1782. ГОДИНЕ
}

\author{
Александар Фотић \\ Универзитет у Београду, Филозофски факултет, Београд, Србија \\ afotic@f.bg.ac.rs
}

\begin{abstract}
Апстракт
На основу изузетно ретког османског документа из готово недоступног Архива Јерусалимске патријаршије, анализирани су подаци о разбојничком чину и смртном рањавању монаха у Јашуњском манастиру 1782. године. По свој прилици, документ се ту обрео као део заоставштине јашуњског монаха Гаврила, који је кренуо на хаџилук и преминуо у Јерусалиму. Указано је на правну процедуру и однос османских власти према манастирима у случајевима разбојничких провала. Потврђују се ставови о порасту криминала у осиромашеним османским европским провинцијама током друге половине 18. века.
\end{abstract}

Кључне речи: Јашуњски манастир, разбојништво, 1782. година, лесковачки кадијски суд, Османско царство.

\section{AN ACT OF BANDITRY AGAINST THE JAŠUNJA MONASTERY IN 1782}

\begin{abstract}
The Ottoman archival material kept in the practically inaccessible Archive of the Jerusalem Patriarchate includes a very important document which testifies to an act of banditry against the "Jašunja monastery" in 1782. The outcome was one lethally wounded monk. The most reasonable explanation for the document ending up in the Archive of the Patriarchate of Jerusalem is that it was found among the effects of monk Gavril who had obviously set out on a pilgrimage, but then died in Jerusalem. The analysis of the document is instructive of the legal procedure followed by the Ottoman authorities and their conduct towards the monasteries in the case of robberies. The document also substantiates the view that the Ottoman Empire's impoverished European provinces saw an increasing crime rate in the second half of the 18th century.
\end{abstract}

Key words: Monastery of Jašunja, banditry, 1782, Leskovac kadı court, Ottoman Empire. 
Вишевековни значај јашуњских манастира Светог Јована Претече и Ваведења Свете Богородице за духовни живот лесковачког краја је неспоран. Ипак, о њима се сразмерно веома мало зна. ${ }^{1}$ Предмет истраживања у овом раду јесте један изузетно редак и драгоцен османски документ из 1782. године. Документ пружа необично занимљиве податке о Манастиру Светог Јована Претече и о његовим монасима, као и о правној процедури османских власти у случајевима разбојничких упада у манастире. Нови подаци умногоме ће обогатити наша сазнања како о самој светињи тако и о безвлашћу у Лесковачком кадилуку током друге половине 18. века.

Оба манастира подигнута су у време када су ти крајеви увелико били у Османском царству, први неупоредиво познатији 1516/17, а други 1499. године. Кренувши трагом Мирјане ЋоровићЉубинковић, академик Гојко Суботић разрешио је многе недоумице из историје Манастира Светог Јована Претече. Пажљиво је прикупио све познате историјске податке, коначно разрешио нејасне натписе и у новом хронолошком контексту анализирао архитектуру и живопис (Ћоровић-Љубинковић, 1950, стр. 229-236; Суботић, 1987, стр. 2336; Суботић, 1988-1989, стр. 77-92; Суботић, 1991, стр. 17-30). ${ }^{2}$

\section{ДРУШТВЕНО-ИСТОРИЈСКИ КОНТЕКСТ И АНАЛИЗА ДОКУМЕНТА}

Друштвене и економске прилике у Лесковачкој нахији, којој је припадало Јашуње, обрађене су на основу података из османских царских пописа из 16. века. Много више података у вези са историјом шире околине манастира̂ сачувано је за 18. век. Они су омогућили да се упознамо с турбулентним приликама у Лесковачком кадилуку у доба велике институционалне и економске кризе Османског царства, поготово са читлучењем и све већом самовољом локалних моћника (Зиројевић, 1969, стр. 165-170; Зиројевић, 1983, стр. 211-268; Васић, 1966-1967, стр. 41-60; Васић, 1972, стр. 49-72; Тричковић, 1971, стр. 5-23).

Изузетно су ретки изворни подаци о јашуњским манастирима пре 19. века. Пронађено је свега неколико података у османским по-

\footnotetext{
${ }^{1}$ Рад је у скраћеном облику претходно био прочитан на научном скупу Јужни српски крајеви у XIX и XX веку: друштвено-економски и политички аспект, Врање, 8-9. 12. 2017.

2 Досадашња сазнања сумирана су у монографији: Јашуњски манастир Светог Јована Претече: пет векова / Jašunja's Monastery of Saint John the Forerunner Baptist: Five Centuries (Пејић, Ниношевић и Трајковић, 2017).
} 
писним дефтерима из 16. века (Зиројевић, 1984, стр. 111). Зато је сваки новопронађени документ изузетно драгоцен. Међу османском грађом, иначе недоступног Архива Јерусалимске православне патријаршије, чува се један веома значајан документ који сведочи о разбојништву извршеном у, како стоји, „Јашуњском манастиру” ('А фхєіо

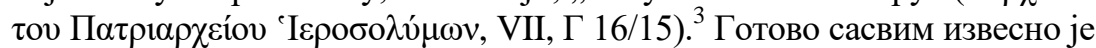
у питању био Манастир Светог Јована Претече, који се налазио у синору села Јашуња и којег је околни народ у 19. веку управо тако и звао (Веселиновић, 1910, стр. 338-357; Зиројевић, 1984, стр. 111). Хуџет лесковачког наиба, кадијиног заступника и помоћника, иначе најранији до сада пронађени акт лесковачког кадијског суда, веома је интересантне садржине, са врло сликовитим описом догађаја. ${ }^{4}$

Монах Гаврил из „Јашуњског манастира” појавио се у уторак 22. фебруара 1782. године (5. марта по новом календару) у судници лесковачког кадије пред наибом Сејидом Мехмедом и пожалио се на зулум. У лесковачку судницу дошао је јер су јашуњски манастири административно и судски припадали Лесковачком кадилуку. Монах Гаврил је од наиба затражио да истражи и расветли разбојнички напад на монахе и смртно рањавање сабрата Јована. У изјави је прецизно одредио време препада, а потом га је детаљно описао. Претходно вече, како Гаврил рече, „у два сата [од почетка] вечери дана уторка”, док су монаси мирно боравили у свом конаку (употребљена је реч $\underline{h} \bar{a} n)$, разбојници (eşkiyā) бешлија хаџи Мустафа и Ахмед Ћорбекироглу, уз помоћ четворице-петорице напасника, изненада су провалили у манастир. Том приликом су монаха Јована снажно ударили сечивом „распоривши га по десној страни, од рамена до струка”. Смртно рањеног сабрата монаси су потом положили у кола. На Гаврилов захтев, у име суда је у манастир послат други наиб по имену Вели. После увиђаја, када се вратио, посведочио је да су Гаврилови наводи тачни. Правни поступак је уписан у кадијину књигу протокола (сииил) и на основу тога је лесковачки наиб Сејид Мехмед издао хуџет монаху Гаврилу.

Приликом првог рашчитавања документа, двоумио сам се око датума: да ли је у питању 1762. или 1782. година. Седма и девета деценија у хиџранској години често се пишу готово истоветно. На читање године 1762, тј. 1176. по хиџри (sene sitt ve seb 'in ve mi'e ve elf), сугерише једна тачкица испод речи која означава деценију, а која би могла да буде саставни део арабичког слова $b a$. Овде је од помоћи

\footnotetext{
${ }^{3}$ У попису Архива Јерусалимске патријаршије дат је само кратак наслов документа, преписан с полеђине. Наслов не указује на Јашуњски манастир и Лесковачки кадилук. Штавише, наслов сугерише да је у питању напад на монахе са

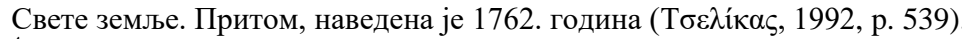

${ }^{4}$ Хуџет (hüccet) јесте акт кадије, његова одлука, пресуда, потврда (Фотић, 1999).
} 
чињеница да је дат тачан датум издавања хуџета (20. реби ул-евел). Ако се определимо за 1762. годину, то би значило да се злочин догодио четири дана раније, јер када се датум прерачуна, добија се субота 28. септембар (9. октобар) 1762. године. Проблем је решен на основу ретко детаљне, па самим тим и драгоцене, изјаве монаха Гаврила, дате на начин какав се не среће често у документима. Он је недвосмислено изјавио да су разбојници упали „вече пре датума ове књиге”, тј. у понедељак. Када се година прочита другачије, као 1196. година по хиџри (sene sitt ve tis 'in ve mi'e ve elf), онда нам се решење питања датирања јасно указује. Датум 20. реби ул-евел 1196. године по хиџри јесте уторак 22. фебруар (5. март) 1782. године, потпуно у складу с Гавриловом изјавом.

Ето како једна тачкица, за коју на основу снимка не можемо да утврдимо да ли води порекло од писарског пера или се ту нашла неким другим, природним путем, може да унесе читаву збрку и учини документ две деценије старијим. С методолошке стране, ово нас опомиње колико је лако погрешити и колико опрезни морамо бити при тумачењу једног издвојеног документа, ван контекста, документа који говори о догађајима који се не могу потврдити другом грађом.

Када су разбојници провалили у манастир? Монах Гаврил се на кадијском суду врло прецизно изјаснио о времену рањавања: „Вече пре датума ове књиге, у два сата [од почетка] вечери дана уторка". Ту је сада потребно да се мало више задржимо на објашњењу исламског рачунања времена почетка и краја дана, рачунања које је настало на претходним традицијама Блиског истока, код Јевреја, а потом усвојено и у Византијском царству. У Османском царству дан је био подељен на две целине од по дванаест сати. Према ханефитској школи шеријата, на којој су се заснивала званична тумачења шеријата у Османском царству, дан је започињао вечерњом молитвом, акшам-намазом, најављеним од стране мујезина. На овим географским просторима вечерња молитва најављивана је углавном негде између 18 и 20 часова предвече, у зависности од годишњег доба. Требало би да акшам-намаз започне у време нестанка сунца с хоризонта, а да се заврши када на небу не буде беле видљиве светлости, тј. кад падне мрак (Blois, 1999; Hitzel, 2012, pp. 11-37; Wishnitzer, 2015). У мањим насељима време отпочињања дана највероватније је одређивао хоџа или мујезин, ако није постојао мувекит (особа задужена да брине о сатници молитава, присутна у свим већим џамијама) (Aydüz, 2006; Wishnitzer, 2015, pp. 25-32). У Истанбулу је постојао мунеџим-баши, главни астроном (у исто време и астролог), задужен за израђивање годишњег календара, особа на основу чијих су смерница стотине мувекита одређивале прецизно време одржавања свих пет дневних молитава у Истанбулу. И када су у 19. веку уведени механички сатови, традиција се одржала дуже време (Aydüz, 1995, pp. 
159-207; Shefer-Mossensohn, 2015, pp. 51-52). У складу с наведеним чињеницама, изјава „у два сата [од почетка] вечери дана уторка”, у ствари значи да се злочин догодио у понедељак, нешто пре 20 часова.

Зашто је монах Гаврил дошао код кадије, затражио да се случај истражи и да о томе добије овакав документ који није ништа друго до обично регистровање смртног рањавања? Гаврил не описује шта се још десило, да ли је било пљачке, када су разбојници побегли, нити даје друге детаље. Чин регистровања рањавања са највероватнијим смртним исходом био је неопходан како би се скинула одговорност са самог Гаврила, а можда и других монаха, ако их је било у манастиру. Врло је вероватно да је Гаврил био игуман манастира и да је стога он наступио у име братства. Свако рањавање, а поготово смрт, обавезно су морали да се пријаве властима (Фотић, 2005, стр. 50-51). Овде није у питању спречавање државних службеника да се докопају покојниковог иметка у корист државне благајне (Бејт улмала), на шта су имали право уколико иза покојника није било наследника. Имовина преминулих монаха до укупне суме од 5000 акчи остајала је у манастиру или је ишла у патријаршијску касу. За државну благајну узимало се све преко те суме. То се ретко дешавало јер је тако богатих монаха било изузетно мало. У 18. и 19. веку гранична сума се више и не помиње у бератима патријараха (Фотић, 2000, стр.

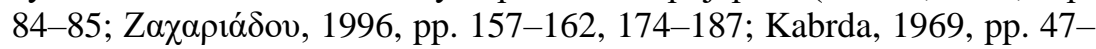
$48,84-86)$. Истрага је била неопходна због утврђивања кривца, како би се у корист државе наплатио десетак од крвнине (одштете). Ако се кривац не би именовао, власти би новац наплатиле од монаха јер се крв пролила унутар манастира (Фотић, 2000, стр. 176; Неуd, 1973, pp. 308-311; Матковски, 1973). Османске власти су у Лесковачком кадилуку током друге половине 18. века неретко учествовале и подстицале убиства како би убрале што веће износе на име крвнине. О томе сведоче жалбе становништва упућиване Порти 1747. и 1757. године, и то на понашање самог санџак-бега. Приход није био мали. Лесковачки мутеселим је 1744. године на име десетка од крвнине узео читаве 2000 грошева! (Тричковић, 1971, стр. 19-20). То је разлог зашто је монах Гаврил затражио да се један наиб одмах упути на лице места да изврши увиђај. Није зато чудно што је Гаврил тај документ толико ценио и што га је понео чак и на хаџилук.

Не знамо како је дошло до сукоба. Могуће је да су напасници хтели да злоупотребе тзв. право на конак и гошћење, иако нису путници (Фотић, 2005, стр. 37). Видимо да су били настањени у околини и да су међу сведоцима овог правног чина (şühüd ül-hăl) на кадиј- 
ском суду наведени један бег и један спахија. ${ }^{5}$ Сасвим је могуће да су злочинци припадали неком од локалних војних родова присутних и у мањим утврђењима (један је назван бешлијом). Кадија није могао да суди припадницима војног сталежа (сталежа аскера) - за њих су биле надлежне војне судије, али је имао право да изврши истрагу и да о томе сачини документ (Imber, 2002, pp. 245-251; Jennings, 1978, pp. 161-164). Без обзира на то да ли су у питању војна лица или обични разбојници, на санџак-беговим људима је било да их гоне и затварају. О безбедности унутар једног санџака бринули су војвода и субаша (Hеyd, 1973, pp. 254-275; Jennings, 1978, pp. 148-150, 165-169; İlgürel, 1981, pp. 12751281).

Један интересантан детаљ такође вреди поменути. Бег који је присуствовао и сведочио утврђивању чињеничног стања звао се Хумбараџи Али-бег. Нема никакве сумње да је Хумбараџи Али-бег био изданак истакнуте породице локалних ајана (првака, локалних достојанственика) из редова заима и спахија, који су се обогатили формирајући велике чифтлике од одузетих сељачких баштина и поседа како Срба тако и муслимана. У свом драгоценом раду о Лесковачком кадилуку у 18. веку, Р. Тричковић је неколико пута указала на моћног лесковачког ајана, осведоченог насилника Мехмед-бега Хумбараџића, спахију села Биљанице, и његовог сина Хасана, који су били узрок бројних жалби локалног живља од 1744. до 1762. године. Мехмед-бег је постао економски толико јак да је 1757. године откупио црнотравске и власинске самокове са све радницима на њима за преко 1700 грошева. Прерада гвоздене руде била је један од најозбиљнијих привредних подухвата у том крају. Држава је рудна места давала у закуп тражећи петину производа (Тричковић, 1971, стр. 1618, 21). Појава Хумбараџи Али-бега 1782. године међу сведоцима судског документа о злочину у Јашуњу говори о томе да се породица успешно одржала на водећим позицијама бар још две деценије.

Нажалост, не знамо ништа више о судбини монаха Гаврила. Нема сумње да се упутио на дуги и опасни пут да се поклони Светом гробу и другим хришћанским светињама. Свакако је стигао у Јерусалим, где је највероватније и преминуо, по свему судећи у неком православном манастиру. Његова заоставштина извесно није могла бити велика. За сада не знамо да ли је, поред приказаног хуџета у Архиву Јерусалимске патријаршије, сачуван још неки документ из његове личне заоставштине. Архив је пребогат арапским и османским документима који говоре о присуству српске православне заједнице на Светој земљи, нарочито о манастирима којима су једно време управ-

${ }^{5}$ О институцији „сведоци чина” в. рад „Хришћани као сведоци чина (suhud ul-hal) на кадијским судовима у Османском царству” (Крешић, 2014, стр. 23-34). 
љали Срби. То су Мар Михаил, Манастир арханђела Михаила, у непосредној близини Цркве Васкрсења Христовог, и Мар Саба, чувена Велика лавра Светог Саве Освећеног у Јудејској пустињи. Има докумената и о ходочасницима. За српску историју би такође биле веома значајне бројне књиге пописа поклоника, њихових дарова и закупа келија у којима су боравили, а које се односе на другу половину 19.

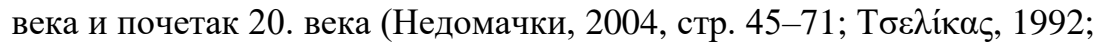
Fotić, 2012).

После Београдског мировног споразума потписаног 1739. године, подручје Лесковачког кадилука преплављено је отпуштеним војницима, махом Арбанасима, и придошлицама из арнаутских крајева, који су се силом насељавали на запустелој земљи. У којој је мери завладало хаотично стање, безвлашће, пљачке и зулуми различите врсте - понајбоље илуструје чињеница да су одметници могли формирати такву војску која је опседала чак и са̂м Лесковац 1741. године. Домаћи муслимани из Ниша, Прокупља и Лесковца деценијама су се жалили Порти на зулуме дошљака. Жалбе раје биле су неупоредиво бројније. Из Истанбула су редовно стизали фермани којим су се наређивале истраге, кажњавања и протеривање силника и разбојника. Међутим, они се нису обазирали на законе, подсмевајући се султанској вољи. Нису се либили да нападну пиротског митрополита док је убирао државни данак 1777. године у селу Кутини, опљачкају га и сасеку његову пратњу, делом састављену и од муслиманских јасакчија. Пораст криминала, међусобни сукоби припадника различитих војних редова, те спахија и читлук-сахибија, као и само читлучење, довели су рају до саме границе издржљивости (Тричковић, 1971, стр. 12-20).

\section{ЗАКЉУЧНА РАЗМАТРАҢА}

Одјеци ове суморне, безнадне и крваве свакодневице очитују се и у овом ретком хуџету лесковачког наиба из 1782. године, сведочанству о препаду и смртном рањавању једног монаха Јашуњског манастира. Документ нам је омогућио да разумемо пуну правну процедуру у којој је активно учествовао монах Гаврил, по свему судећи, игуман манастира. Значај документа потврђује и чињеница да га је Гаврил понео на далеки пут у Свету земљу, где је највероватније и окончао свој живот. С друге стране, бачено је нешто више светла и на са̂м Јашуњски манастир, толико ретко помињан у историјским изворима. Зато овај документ вреди објавити у целини и с научном транскрипцијом - тим пре што је то једини познати акт лесковачког шеријатског суда из периода пре 19. века. 


\section{ПРИЛОГ}

Хуџет

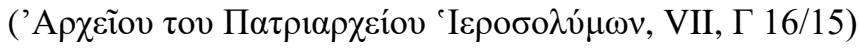

Он!

[Овера]

Оно што је овде је истражено и записано. Ово написа убоги - нека се увећа Његова слава - Сејид Мехмед, кадија у заступству [наиб] у граду Лесковцу. Нека му је опроштено!

[Печат] Сејид Мехмед [...?]

Разлог писању правоваљане књиге је следећи:

Овај узрок документа, житељ Јашуњског манастира који од почетка [административно] припада касаби Лесковац, монах по имену Гаврил пред узвишеним шеријатским скупом који захтева поштовање овако је изјавио и пожалио се на зулум:

„Вече пре датума ове књиге, у два сата [од почетка] вечери дана уторка, док смо ми мирно боравили у свом конаку, становници [топоним неразумљив] разбојници по имену бешлија хаџи Мустафа и Ахмед Ћорбекироглу, са пратиоцима, њих четири-пет разбојника, дошли су и изненада провалили у поменути манастир. Мог сабрата, монаха по имену Јована, снажно су ударили и ранили га сечивом, распоривши га по десној страни, од рамена до струка. Пошто ће вероватно умрети, сада је [положен] у кола. Мој је захтев да [случај] истражите и расветлите и [предате] ми у руке потписани шеријатски хуџет".

Пошто је то изјавио, од стране суда одређен је и послат наиб Вели. После увиђаја и истраге [утврдио] је да је поменути заиста рањен сечивом по десној страни од врха рамена до струка и да му је стомак распорен. Пошто је поменути наиб дошао на шеријатски скуп и известио и саопштио шта се догодило, стварно стање је записано и убележено. Ово је протекло и написано је двадесетог дана реби улевела хиљаду сто деведесет и шесте године [22. 2 / 5. 3. 1782].

Сведоци чина:

Славни међу једнакима, Хумбараџи Али-бег; имам Омер ефендија; хаџи Дервиш; Хасан спахија; Хасан-беше, [који] припада судници; Хасан челебија, позивар; Исмаил, син Алија.

[Запис на полеђини] [Да су] упали неки Турци и пребили Агиотафите Гаврила и оне око њега. ${ }^{6}$

\footnotetext{
6 За превод грчког записа на полеђини захваљујем проф. др Дарку Тодоровићу.
} 


\section{Транскрипиија:}

Hüve!

[Овера]

Mā fỉhi min el-keşf ve-t-taḳrīr. Namaḳahu el-faḳīr ileyhi 'azze şānuhu // Es-seyyid Meḥmed el-müvellā hֵilāfeten be-medīne-i Lesḳofçe. // 'Ufiye 'anhu.

[Печаm] Es-seyyid Mehmed [...?]

[1] Sebeb-i taḥrīr-i kitāb-i ḥaḳị̣ oldur ki: [2] Fī-1-āṣl Lesḳōfçe ḳaṣabası mużāâtından Yaşīne manāstırı mütemekkinlerinden işbu bā'is ül-veșiḳa Ġavrīl [3] nām keşiş meclis-i şer'-i hatịîr ve lāzım ut-tevḳîrde şöyle taḳrīr-i kelām ve tażallüm-i hāa èder ki tārịh-i kitābdan [4] bir gèce muḳaddem yevm-i șalı gècesi sā't ikide iken bizler kendi hāanumuzda kendi hnāllerümüzde olub Bașir Hạk Toplu [?] [5] sükkānından beşli El-ḥāc Muștafā ve Kör Bekiroğlu Aḥmed nām şāḳ̣̂ ve refîkleri dört beş nefer eşkiyālar ile gelüb manāstır-i merḳūme [6] bașub ve refiküum Yōvān nām keşiş żarb-i şedīd żarb ve ẓūbe ${ }^{8}$ ile șag țarafindan omuzdan [7] beline değin urub belini kirub mecrūḥ eylemişlerdür fevt olunmak ị̣timāli olmag̉la hạalā [8] mesfūr Yōvān 'araba içinde olub țarafinuzdan keşf ü naz̧ar ve yedimüñüzi ${ }^{9}$ hü̈ccet-i şer'iye imżāsı [9] mațlūbumdur deddikde țaraf-i şer'iden monlā Velī ta'yīn ve irsāl olunub mezbūr Yövān [10] keşiş ${ }^{10}$ eserer$\overline{1}^{11}$ mecrūhuna ba‘d en-naẓar fî-l-vāḳı ${ }^{`}$ mesfüruñ omuzı başindan șag țarafindan [11] beline değin zūbe ile mecrūḥ ve beli kıırık dèyü mu'ayyene ve müşāhede eyledükdenșoñra mevlānā-ȳi [12] mezbūr 'alā vukū'ihi meclis-i şer'a gelüb inhā ve ihhbār etmegin ol ki vāḳi' ül-ḥālı [13] ketb ü terḳīm olundı. Cerā zalike tahrīren fị ${ }^{12}$ yevm ül-'işrīn Rebī‘ ül-evvel sene sitt ve tis'în ve mi'e ve elf.

Şühūd ül-hạal:

Faḥr ul-aḳrān Humbaracı 'Alī Beg ve imām 'Ömr Efendī ve El-ḥāc Dervīş, Hasan sipāhī, Hasan Beşe tabi`'-i mehkeme, Hasan Çelebi muȟ̀īìr, İsmā'il bin 'Alī.

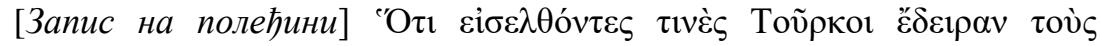

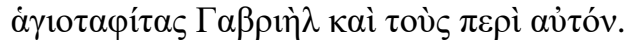

\footnotetext{
${ }^{7}$ Треба да пише şak̄ī.

${ }^{8}$ Треба да пише zube.

${ }^{9}$ Треба да пише уedimüzi.

${ }^{10}$ Треба да пише keş̄ş, како је уосталом претходно једанпут и написао. Има и других показатеља да писар није био превише образован. Често изоставља nām после имена.

${ }^{11}$ Треба да пише eser-i.

12 Треба да пише cerā żalike ve hurīre fì, како је то уобичајено у хуџетима.
} 
168

Документ

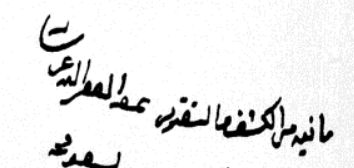

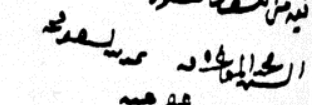

קse

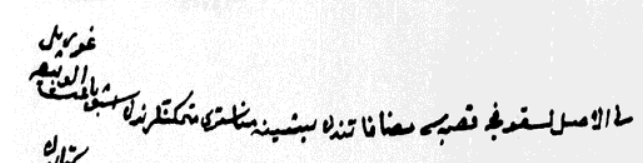

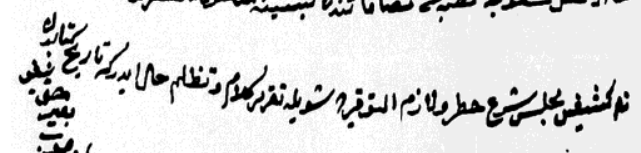

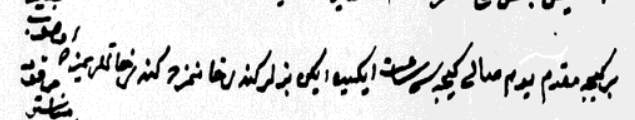

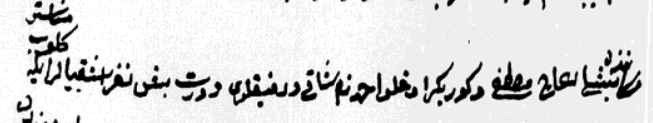

اريزّة

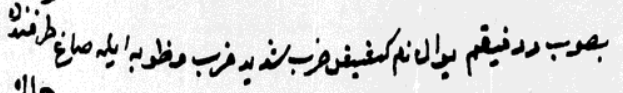

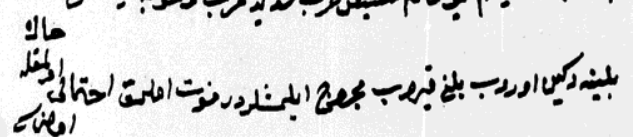

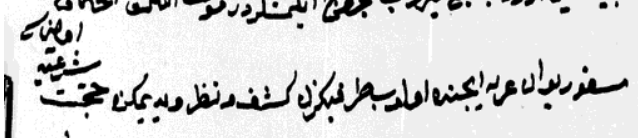

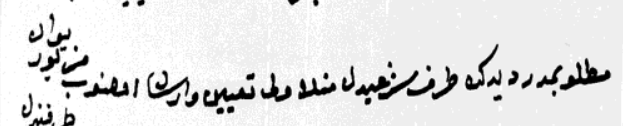

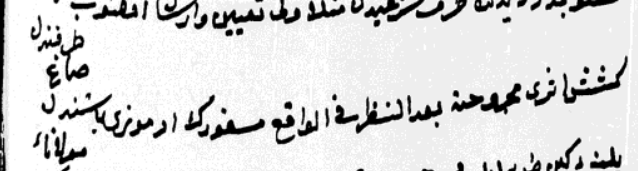

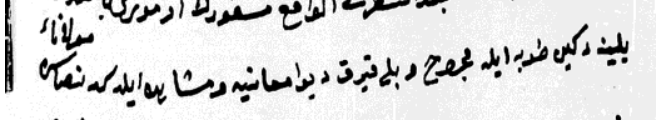

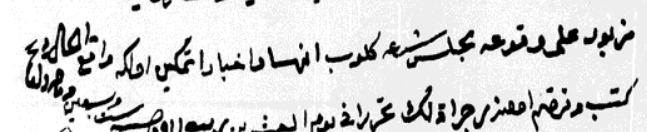

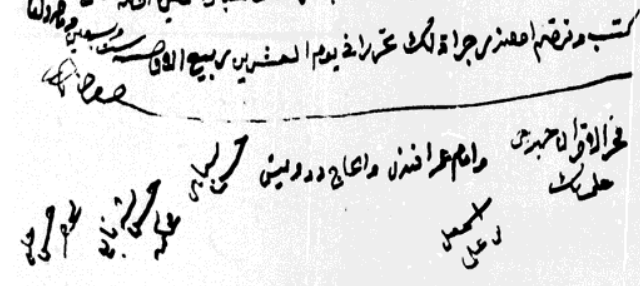




\section{ИЗВОРИ}

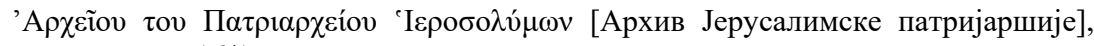
VII, Г 16/15.

\section{ЛИТЕРАТУРА}

Ayduz, S. (1995). Osmanlı Devleti'nde Muneccimbaşıllk. Osmanlı Bilimi Araştırmaları, 1, 159-207.

Aydüz, S. (2006). Muvakkithâne. In Türkiye Diyanet Vakfi İslâm Ansiklopedisi: Muhammediyye - Münâzara (Vol. 31, pp. 413-415). Ankara: Türkiye Diyanet Vakfi.

Blois, F. C. de. (1999). Ta'rikk. I. Dates and Eras in Islamic World. 1. In the Sense of 'Date, Dating', etc. In Encyclopaedia of Islam. CD-ROM Edition v. 1.0. Leiden: Koninklijke Brill NV.

Ћоровић-Љубинковић, М. (1950). Јашуњски манастири [Jašunja Monasteries]. Старинар, I, 229-236.

Фотић, А. (1999). Хуџет [Нüccet]. У С. Ћирковић и Р. Михаљчић (Прир.), Лексикон српског средњег века [The Lexicon of Serbian Middle Ages] (стр. 787-788). Београд: Knowledge.

Фотић, А. (2000). Света Гора и Хиландар у Османском ияарству XV-XVII век [Mount Athos and Hilandar in the Ottoman Empire $15^{\text {th }}-17^{\text {th }}$ Centuries]. Београд: Балканолошки институт САНУ, Манастир Хиландар, Свети архијерејски синод Српске православне цркве.

Fotić, A. (2012). Serbian Orthodox Christian Community in Ottoman Jerusalem (16$17^{\text {th }}$ C.): Sources, Interpretations and Historiographical Problems. Саопштење на научном скупу $20^{\text {th }}$ CIÉPO Symposium: New Trends in Ottoman Studies, 27 June - 1 July 2012. Rethymno. У припреми за штампу.

Фотић, А. (2005). „Између закона и његове примене [Between the Law and its Enforcement]”. У А. Фотић (Прир.), Приватни живот у српским земљама у освит модерног доба [Private Life in Serbian Lands at the Dawn of Modern Era] (стр. 27-71). Београд: Clio.

Heyd, U. (1973). Studies in Old Ottoman Criminal Law. V. L. Ménage (Ed.). Oxford: At the Clarendon Press.

Hitzel, F. (2012). De la clepsydre à l'horloge. L'art de mesurer le temps dans l'Empire ottoman. In F. Georgeon, F. Hitzel (Sous la direction de), Les Ottomans et le temps (pp. 11-37). Leiden-Boston: Brill.

İlgürel, M. (1981) XVII. Yüzyıl Balıkesir Şer'iyye Sicillerine Göre Subaşılık Müessesesi. In VIII. Türk Tarih Kongresi, Ankara 11-15 Ekim 1976, Kongreye Sunulan Tebliğler (Vol. II, pp. 1275-1281). Ankara: Türk Tarih Kurumu.

Jennings, R. C. (1978). Kadi, Court, and Legal Procedure in the 17th C. Ottoman Kayseri. Studia Islamica, 48, 133-172.

Kabrda, J. (1969). Le système fiscal de l' Église orthodoxe dans l'Empire ottoman (d'après les documents turcs). Brno: Universita J. E. Purkyně.

Крешић, О. (2014). Хришћани као сведоци чина (şuhud ul-hal) на кадијским судовима у Османском царству [Christians as Şuhud ul-Hal at Kadi Courts in the Ottoman Empire]. 3борник Матице српске за историју, 89, 23-34.

Матковски, А. (1973). Диетот - крвнината во Македонија и на Балканскиот полуостров за време на турското владеење. Скопје: МАНУ. 
Недомачки, В. (2004). Задужбине Немањића у Светој Земљи [The Nemanjić's Foundations in Holy Land]. У јеромонах Јован (Ћулибрк) (Прир.): Никон Јерусалимач - вријеме, личност, дјело. Зборник радова са међународног научног симпосиона на Скадарском језеру, 7-9. септембра 2000. године [Nikon of Jerusalem - his Time, Personality, and Works. Collection of Papers from International Simposium held on Skadar Lake, 7 - 9 September, 2000] (45-71). Цетиње: Светигора.

Пејић, С., Ниношевић, М. и Трајковић, В. (2017). Јашуњски манастир Светог Јована Претече: пет векова / Jašunja's Monastery of Saint John the Forerunner Baptist: Five Centuries. Лесковац: Народни музеј.

Shefer-Mossensohn, M. (2015). Science among the Ottomans: The Cultural Creation and Exchange of Knowledge. Austin: University of Texas Press.

Суботић, Г. (1987). Зидно сликарство Светог Јована Претече у Јашуњи (1) [Wall Paintings in St John the Baptist in Jašunja (1)]. Лесковачки зборник, XXVII, 23-36.

Суботић, Г. (1988-1989). Из епиграфске грађе поствизантијског доба [From PostByzantine Epigraphy]. Саопитена, XX-XXI, 77-92.

Суботић, Г. (1991). Зидно сликарство Светог Јована Претече у Јашуњи (2) [Wall Paintings in St John the Baptist in Jašunja (2)]. Лесковачки зборник, XXXI, $17-30$.

Тричковић, P., (1971). Лесковац у XVIII веку (1683-1804) [(Leskovac in $18^{\text {th }}$ Century (1683-1804)]. Лесковачки зборник, XI, 5-23.

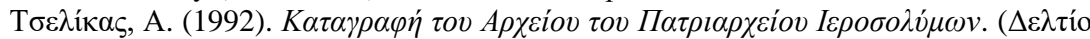

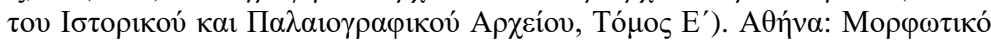

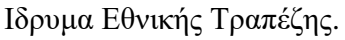

Васић, М. (1966-1967). Лесковац у XVI вијеку [Leskovac in $16^{\text {th }}$ Century]. Годишъак Друштва историчара Босне и Херчеговине, XVII, 41-60.

Васић, М. (1972). Становништво Крушевачког санџака и његова друштвена структура у XVI вијеку [The Population of the Sancak of Kruševac and its Social Structure]. У Стошић А. (Ур.): Крушеваи кроз векове. Зборник реферата са симпозијума одржаног од 4. до 9. октобра 1971. у Крушевиу [Kruševac through Centuries. Conferance Proceedings, Kruševac, 4 -9 October, 1971] (49-72). Крушевац: Народни музеј.

Веселиновић, М. (1910). Јашуњски манастири. Мушки манастир Свети Јован и женски манастир Света Богородица [Jašunja Monasteries. The Male Monastery of St John the Baptist and the Female Monastery of Holy Mother of God]. Годишњица Николе Чупића, XXIX, 338-357.

Wishnitzer, A. (2015). Reading Clocks, alla Turca: Time and Society in the Late Ottoman Empire. Chicago: The University of Chicago Press.

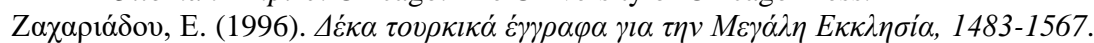

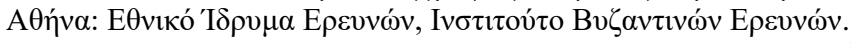

Зиројевић, О. (1969). Лесковац у XV и XVI веку [Leskovac in $15^{\text {th }}$ and $16^{\text {th }}$ Centuries]. Лесковачки зборник, IX, 165-170.

Зиројевић, О. (1983). Лесковац и његова нахија од 1455. до 1683. године [Leskovac and its Nahiye from 1455 to 1683]. Лесковачки зборник, XXIII, 211-268.

Зиројевић, О. (1984). Цркве и манастири на подручју Пећке патријариије до 1683. године [The Churches and Monasteries from Peć Patriarchate till 1683]. Београд: Историјски институт - Народна књига. 


\title{
AN ACT OF BANDITRY AGAINST THE JAŠUNJA \\ MONASTERY IN 1782
}

\author{
Aleksandar Fotić \\ University of Belgrade, Faculty of Philosophy, Belgrade, Serbia
}

\begin{abstract}
Summary
Original information on the Jašunja monasteries is exceptionally rare before the 19th century. The Ottoman archival material kept in the practically inaccessible archive of the Jerusalem Patriarchate includes a very important document which testifies to the act of robbery committed in the "Jašunja monastery", most likely the monastery of St John the Forerunner. In the early evening of Monday, February $22^{\text {nd }} 1782$, a few Muslim men broke into the monastery and lethally wounded a monk, Jovan, ripping him open from shoulder to stomach with a blade. Another monk, Gavril, immediately informed the kadı of Leskovac, asking that an investigation be conducted and a hüccet (the kadi court document) about it made. The most reasonable explanation for the hüccet ending up in the archive of the Patriarchate of Jerusalem is that it was found among the effects of monk Gavril who had obviously set out on a pilgrimage some time after the robbery, managed to pay his respects to the Holy Sepulchre but then died there. The analysis of the document is instructive of the legal procedure followed by the Ottoman authorities and their conduct towards the monasteries in the case of robberies. The document also substantiates the view that the Ottoman Empire's impoverished European provinces saw an increasing crime rate in the second half of the $18^{\text {th }}$ century.
\end{abstract}

